\title{
Correction to: Beneficial effects of the nutritional supplements on the development of diabetic retinopathy
}

Renu A. Kowluru ${ }^{1 *}$, Qing Zhong ${ }^{1}$, Julia M. Santos ${ }^{1}$, Mangayarkarasi Thandampallayam ${ }^{1}$, Doug Putt ${ }^{1}$ and Dennis L. Gierhart ${ }^{2}$

\section{Correction to Nutrition \& Metabolism 2014,11:8} http://www.nutritionandmetabolism.com/ content/11/1/8

Following the publication of the original article [1], the authors identified an error in Fig. 1. The correct figure is given below.

The original article [1] has been corrected.

The original article can be found online at https://doi.org/10.1186/1743-7075-

$11-8$.

${ }^{*}$ Correspondence: rkowluru@med.wayne.edu

${ }^{1}$ Department of Ophthalmology, Kresge Eye Institute, Detroit, MI, USA

Full list of author information is available at the end of the article original author(s) and the source, provide a link to the Creative Commons licence, and indicate if changes were made. The images or other third party material in this article are included in the article's Creative Commons licence, unless indicated otherwise in a credit line to the material. If material is not included in the article's Creative Commons licence and your intended use is not permitted by statutory regulation or exceeds the permitted use, you will need to obtain permission directly from the copyright holder. To view a copy of this licence, visit http://creativecommons.org/licenses/by/4.0/. The Creative Commons Public Domain Dedication waiver (http://creativeco mmons.org/publicdomain/zero/1.0/) applies to the data made available in this article, unless otherwise stated in a credit line to the data. 
a

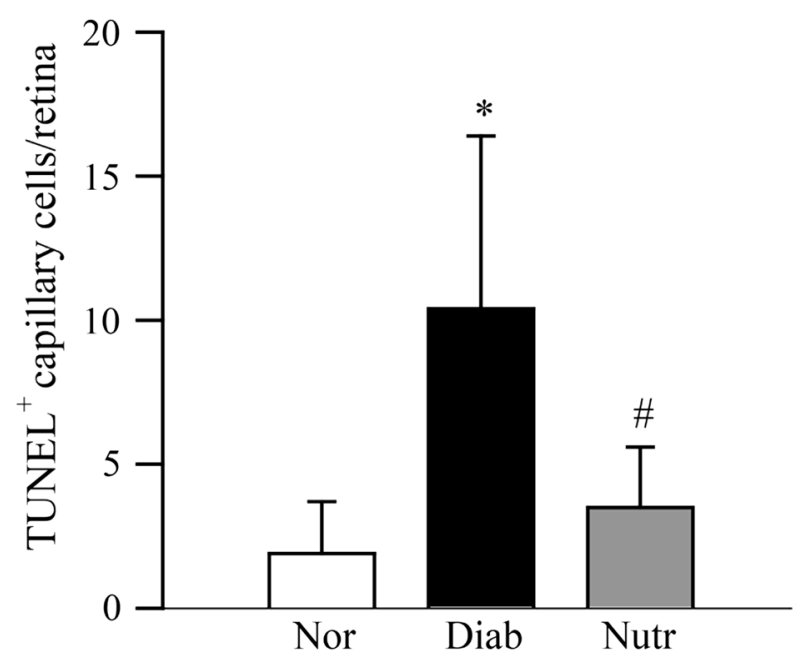

b

Diab

Nutr
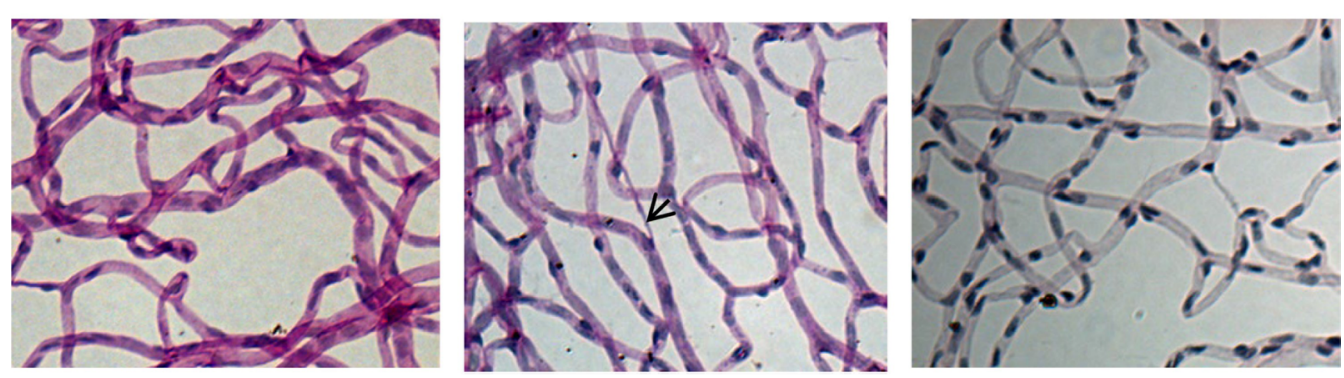

C

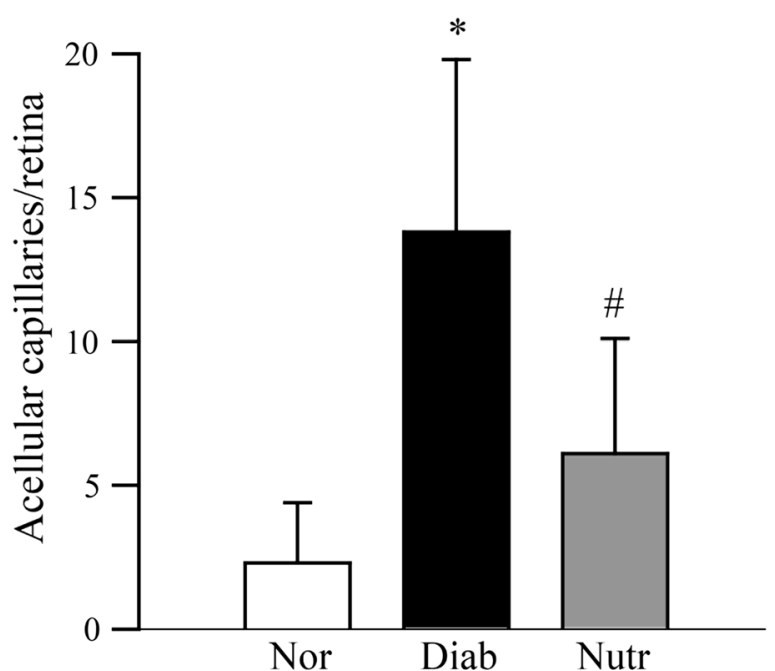

Fig. 1 Nutrient administration inhibits retinal capillary cell apoptosis and degeneration in diabetic rats. Trypsin digested retinal microvasculature was (a) analyzed for capillary cell apoptosis by TUNEL staining. (b) After TUNEL staining, the microvessels were stained with periodic acid-Schiff-hematoxylin; the arrow indicates a capillary which has lost endothelial cell. (c) The number of acellular capillaries was counted in the entire retinal vasculature, and represented as number of acellular capillaries/retina. Results are expressed as mean \pm SD of 7-8 rats each in normal (Nor), diabetic (Diab) and diabetic rats receiving the nutrients (Nutr) groups. ${ }^{*} p<0.05$ compared to age-matched normal, and ${ }^{\#} p<0.05$ compared to diabetes 


\section{Author details}

${ }^{1}$ Department of Ophthalmology, Kresge Eye Institute, Detroit, MI, USA. ${ }^{2}$ Zeavision, L.L.C., Chesterfield, MO, USA.

Published online: 05 January 2022

\section{Reference}

1. Kowluru, et al. Beneficial effects of the nutritional supplements on the development of diabetic retinopathy. Nutr Metab. 2014;11:8. https://doi. org/10.1186/1743-7075-11-8.

\section{Publisher's Note}

Springer Nature remains neutral with regard to jurisdictional claims in published maps and institutional affiliations. 